\title{
The prevalence of canine Leishmania infantum infection in Sichuan Province, southwestern China detected by real time PCR
}

\author{
Li-min Shang ${ }^{1}$, Wei-ping Peng ${ }^{2}$, Hong-tao Jin ${ }^{1}$, Ding $\mathrm{Xu}^{2}$, Ni-na Zhong ${ }^{2 *}$, Wen-long Wang ${ }^{2}$, You-xi $\mathrm{Wu}^{3}$ and \\ Quan Liu ${ }^{1 *}$
}

\begin{abstract}
Background: Visceral leishmaniasis $(\mathrm{VL})$ is endemic in western China, and becoming an important public health concern. Infected dogs are the main reservoir for Leishmania infantum, and a potential sentinel for human VL in endemic areas. In the present study we investigated the prevalence of Leishmania DNA in dogs from Wenchuan, Heishui and Jiuzhaigou County in Sichuan Province, southwestern China, which are important endemic areas of zoonotic $\mathrm{VL}$, detected by real time PCR. The results will help to design control strategies against visceral leishmaniasis in dogs and humans.

Results: The overall prevalence of Leishmania DNA in dogs was 24.8\% (78/314) in Sichuan Province, with the positive rate of 23.5\% (23/98) in Wenchuan County, 28.2\% (20/71) in Heishui County, and 24.1\% (35/145) in Jiuzhaigou County, and no significant difference was observed among the three counties $(P>0.05)$. The dogs were further allocated to different groups based on sexes, ages and external clinical symptoms. The logistic regression analysis revealed that a higher prevalence was found in older and external symptomatic dogs, compared to that of younger and asymptomatic dogs $(P<0.05)$.

Conclusions: The results revealed that L. infantum infection in dogs is widespread in Sichuan Province, southwestern China, which has a public health significance, due to its contribution to the transmission of the infection to humans by sandflies. It is necessary to take measures, including treatment or eradication of infected dogs, to control canine leishmaniasis, which could be helpful to reduce human VL in this area.
\end{abstract}

Keywords: Leishmania, Dogs, Prevalence, Real time PCR, China

\section{Background}

Visceral leishmaniasis (VL) is a severe sandfly-transmitted parasitic disease in humans caused by protozoans of the Leishmania donovani complex. The disease is endemic in Europe, Asia, Africa and Latin America, and there are about 500,000 new cases per year in the world [1]. VL has also become an important opportunistic infection related to HIV [2,3]. VL is still an important infectious disease in China, and can be divided into

\footnotetext{
*Correspondence: zhongnina45@yahoo.com.cn; liuquan1973@hotmail.com 1 Institute of Military Veterinary, Academy of Military Medical Sciences, Key Laboratory of Jilin Province for Zoonosis Prevention and Control, 666 Liuying Xilu, Changchun 130122, Jilin Province, People's Republic of China ${ }^{2}$ College of Veterinary Medicine, Sichuan Agricultural University, 46 Xingkang Road, Ya'an 625014, Sichuan Province, People's Republic of China Full list of author information is available at the end of the article
}

three types: natural focal visceral leishmania (NVL), anthroponotic visceral leishmaniasis (AVL) and zoonotic visceral leishmania (ZVL) [4]. NVL is distributed in Xingjiang and Inner Mongolia, where the wild animals are the sources of infection [5,6]. AVL is transmitted between humans in Shandong, Jiangsu, Hebei, Anhui Province, where patients are the main sources of infection [7]. This type of disease has not been found since 1970s, but there are some sporadic cases of cutaneous leishmaniasis in these regions. ZVL is mainly distributed in Gansu, Qinghai, Ningxia, Sichuan, Shanxi, where canine leishmaniasis caused by L. infantum is the important source of human VL [8-10].

Infected dogs are the main reservoir for Leishmania infantum, and can be used as a potential sentinel for

\section{Biomed Central}

(c) 2011 Shang et al; licensee BioMed Central Ltd. This is an Open Access article distributed under the terms of the Creative Commons Attribution License (http://creativecommons.org/licenses/by/2.0), which permits unrestricted use, distribution, and reproduction in any medium, provided the original work is properly cited. 
human VL in the endemic areas [11,12]. Accurate detection of canine leishmaniasis is valuable to prevent transmission to humans. Due to the variable signs of canine leishmaniasis, the clinical diagnosis is not easy [13]. It has been demonstrated that both symptomatic and asymptomatic dogs infected with the parasite are the sources of infection for humans transmitted by the bite of sandfly $[10,14]$. Therefore, surveillance of canine $L$. infantum infection in endemic areas is very important to control VL in humans and animals.

Serological and PCR-based methods have been widely used to investigate canine infection with L. infantum, and PCR-based methods are more sensitive than serological methods [15-19]. Western Sichuan Province, China, including Wenchuan, Heishui and Jiuzhaigou, is an important ZVL endemic area, and also popular with tourists. However, there has been no comprehensive epidemiological survey of canine leishmaniasis in these areas, except a recent study conducted in Jiuzhaigou County [10]. In this study we investigated the prevalence of Leishmania DNA in dogs in the three counties by real time PCR.

\section{Materials and methods Study site}

The study was carried out in Wenchuan County $\left(30^{\circ} 45^{\prime}\right.$ $31^{\circ} 43^{\prime} \mathrm{N}, 102^{\circ} 51^{\prime}-103^{\circ} 44^{\prime}$ E), Heishui County (31 $35^{\circ}-32^{\circ}$ $\left.38^{\prime} \mathrm{N}, 102^{\circ} 35^{\prime}-103^{\circ} 30^{\prime} \mathrm{E}\right)$ and Jiuzhaigou County (32 $53^{\circ}$ $33^{\circ} 32^{\prime} \mathrm{N}, 103^{\circ} 27^{\prime}-104^{\circ} 26^{\prime} \mathrm{E}$ ), located in the mountainous area of western Sichuan Province, southwestern China, where VL is endemic and dogs are important reservoirs for the parasite. Wenchuan County has an annual mean temperature of $13.5 \sim 14.1^{\circ} \mathrm{C}$, with the mean annual rainfall of 529 1,332 mm and mean altitude of 1,325 meters above sea level. Heishui County has an annual mean temperature of $9.5^{\circ} \mathrm{C}$, with the mean annual rainfall of $620 \mathrm{~mm}$ and mean altitude of 3,544 meters above sea level. Jiuzhaigou County has an annual mean temperature of $7.3^{\circ} \mathrm{C}$, with the mean annual rainfall of 700 800 $\mathrm{mm}$ and altitude of 1,140 2,000 meters above sea level. There is a population of 42,600 in Jiuzhaigou, 105,500 in Wenchuan, and 57,000 in Heishui, respectively. In recent years, there were about 20, 10 and several human VL cases reported in Jiuzhaigou, Wenchuan, and Heishui per year, respectively [20]. Phlebotomus chinensis is the predominant species as well as the important transmission vector of VL in western Sichuan Province, southwestern China, and the average prevalence of Leishmania parasites in P. chinensis females is $1.98 \%$ [21].

\section{Animals and sampling}

The protocol for sampling was reviewed and approved by the Animal Ethics Committee of Institute of Military
Veterinary, Academy of Military Medical Sciences (MVI2009-107). Oral consent was obtained from the owners of dogs. There were 5,813, 4,938 and 8,875 dogs in Wenchuan, Heishui and Jiuzhaigou County, respectively. The household dogs were randomly collected at the capital town of the county and adjacent villages in May and June, 2010, and examined for the external clinical signs of the diseases, including weight loss, dry exfoliative dermatitis, ulcers, periorbital alopecia, diffuse alopecia and ocular signs. Two milliliters of blood samples were taken from the foreleg vein of each dog in EDTA-coated polypropylene tubes for isolation of parasite DNA.

\section{DNA extraction}

The Leishmania isolate $\mathrm{MHOM} / \mathrm{CN} / 92 / \mathrm{SC} 10 \mathrm{H} 2$ was originally obtained from Sichuan Province and maintained in our laboratory [22]. The parasite was grown in $\mathrm{NNN}$ medium at $24^{\circ} \mathrm{C}$ for 14 days. DNA extraction from cultured parasite and dog blood samples was carried out using TIANamp Genomic DNA Kit for blood, cell and tissue (Tiangen Biotech Co., LTD, Beijing, China) according to manufacturer's instruction. The extracted DNA was suspended in elution buffer $(10 \mathrm{mM}$ Tris, 1 mM EDTA, pH8.0).

\section{Real time PCR}

Leishmania DNA in peripheral blood was detected by real time PCR using SYBR ${ }^{\circledR}$ Green Real-time PCR Master Mix-Plus (Toyobo Biotechnology) as previously described [23]. The real time PCR was carried out using the primers (forward: 5'-CCTATTTTACACCAACCCCCAGT-3'; reverse: 5'-GGGTAGGGGCGTTCTGCGAAA-3') that amplify the 120 bp fragment of the minicircle kinetoplast DNA of Leishmania. The limit of detection was 0.1 parasite per real time PCR reaction. Genomic DNA from Leishmania reference strain $\mathrm{MHOM} / \mathrm{CN} / 92 / \mathrm{SC} 10 \mathrm{H} 2$ was used as a positive control, and the negative control was established with deionized water instead of DNA extract.

\section{Statistical analysis}

Differences in prevalence of dogs from different sampling sites and among associated factors were analyzed using the Chi square test and logistic regression by SPSS version 11.0 software. The difference was considered statistically significant when $P<0.05$.

\section{Results}

\section{Prevalence of Leishmania DNA in dogs}

A total of 314 household dogs were chosen for real time PCR detection of Leishmania DNA, and 78 (24.8\%) of 214 were found Leishmania-positive in Sichuan Province, southwestern China, with 23 (23.5\%) of 98 in 
Table 1 Prevalence of Leishmania infection in dogs from the three counties of Sichuan Province, China

\begin{tabular}{cccc}
\hline Region & No. of examined & No. of positive & Prevalence (\%) \\
\hline Wenchuan & 98 & 23 & 23.5 \\
Heishui & 71 & 20 & 28.2 \\
Jiuzhaigou & 145 & 35 & 24.1 \\
Total & 314 & 78 & 24.8 \\
\hline
\end{tabular}

Wenchuan, 20 (28.2\%) of 71 in Heishui, and 35 (24.1\%) of 145 in Jiuzhaigou tested positive (Table 1). No significant difference was observed in prevalence among the three counties $(P>0.05)$.

\section{Risk factors for Leishmania infection in dogs}

The dogs were further allocated to different groups, based on sexes, ages and clinical symptoms of VL. These groups included male $(\mathrm{n}=176)$ or female $(\mathrm{n}=$ $138)$, the $\leq 1$ year old $(\mathrm{n}=220)$ or the $>1$ year old $(\mathrm{n}=$ $94)$; and the asymptomatic (presenting no external clinical signs of VL; $\mathrm{n}=241$ ) or the symptomatic (presenting one of the external clinical signs of VL, such as weight loss, dry exfoliative dermatitis, ulcers, periorbital alopecia, diffuse alopecia and ocular signs; $\mathrm{n}=73$ ) (Table 2).

There was no any significant association between sex and the prevalence of infection $(P=0.941)$. However, a significant association between dog age and prevalence of VL was found $(P=0.001)$, with a higher prevalence in $>1$ year old group $(37.2 \%)$ than that in $\leq 1$ year old group (19.5\%). Dogs aged > 1 year old had a much higher risk of acquiring VL infection than those aged $\leq$ 1 year old $(\mathrm{OR}=2.4 ; 1.4-4.2 \mathrm{CI} 95 \%)$. The prevalence (35.6\%) of dogs with external clinical signs was higher when compared with that $(21.6 \%)$ of dogs in which external clinical signs were not found (Table 2).

\section{Discussion}

ZVL caused by the kinetoplastid protozoan L. infantum is still endemic in China, especially in the northwest regions $[24,25]$. The parasite is transmitted to humans by the bite of the sandfly Phlebotomus chinensi, and infected dogs serve as the main reservoir $[9,10]$. Standard measures to control ZVL in China have depended on eradication of infected dogs, vector control and treatment of patients, and these measures have played important roles to prevent the rapid rise and spread of ZVL in China [26]. However, the increased prevalence of L. infantum in dogs would cause local outbreak of ZVL in these regions, and eradication of dogs can markedly reduce the number of human cases [27]. Therefore, the prevalence of $L$. infantum infection in dogs would show trends of ZVL in humans $[11,28,29]$. In this study we collected blood samples from dogs in endemic areas of Wenchuan, Heishui and Jiuzhaigou County, China and evaluated the prevalence of L. infantum infection in these dogs by real time PCR

Based on our results, $24.8 \%$ dogs were detected positive for Leishmania, with the prevalence of $23.5 \%$ in Wenchuan, 28.2\% in Heishui and 24.1\% in Jiuzhaigou, less than those reported by other studies in high endemic areas [10,30-32], while higher than those studies conducted in low endemic regions [33-35]. The results are related to the samples of different endemic areas.

We found that age and external clinical status of dogs are associated with prevalence of Leishmania infection. Dogs aged > 1 year old had higher prevalence of $L$. infantum infection than those aged $\leq 1$ year old, resulting from most likely longer exposure to infective sandfly bites. The dogs with external clinical signs, such as weight loss, dry exfoliative dermatitis, ulcers, periorbital alopecia, diffuse alopecia and ocular signs also had higher prevalence than the asymptomatic dogs. The possible reason would be that the symptomatic dogs have higher parasite load, resulting in a higher detection rate [36]. Our results showed that dogs with no external clinical signs may also harbor Leishmania, although in a lower prevalence as compared to dogs with external clinical signs $[37,38]$.

Table 2 Risk factors for Leishmania infection in dogs from Sichuan Province, China

\begin{tabular}{|c|c|c|c|c|c|}
\hline Data of dogs & No. of examined & No. of positive & Prevalence (\%) & $P$ & OR $(95.0 \% \mathrm{Cl})$ \\
\hline \multicolumn{6}{|l|}{ Sex } \\
\hline Male & 176 & 44 & 25.0 & 0.941 & $0.5(0.2-1.0)$ \\
\hline Female & 138 & 34 & 24.6 & & \\
\hline \multicolumn{6}{|l|}{ Age } \\
\hline$\leq 1$ year & 220 & 43 & 19.5 & 0.001 & $2.4(1.4-4.2)$ \\
\hline$>1$ year & 94 & 35 & 37.2 & & \\
\hline \multicolumn{6}{|l|}{ Clinical status $^{a}$} \\
\hline Symtomatic & 73 & 26 & 35.6 & 0.015 & $2.0(1.1-3.6)$ \\
\hline Asymtomatic & 241 & 52 & 21.6 & & \\
\hline
\end{tabular}

\footnotetext{
a The clinical status including the asymptomatic dogs, which present no clinical signs of $\mathrm{VL}$, and symptomatic dogs, which present one of the external clinical
} signs of VL, such as weight loss, dry exfoliative dermatitis, ulcers, periorbital alopecia, diffuse alopecia and ocular signs. 
The serological and PCR-based methods are sensitive and specific to investigate canine leishmaniasis. For detection in symptomatic dogs, the sensitivity of two methods is comparable. But for asymptomatic dogs, the PCR method is more sensitive than serological methods [39-41]. The probable reason is that asymptomatic infection dogs have low parasite burden and antibody levels, while the detection limit of PCR can be a single parasite. Our results, combined with other studies, demonstrated that real time PCR is a reliable method to detect Leishmania DNA in dogs. However, a comprehensive evaluation of PCR combined with clinicopathological and serological results is important to diagnose canine leishmaniasis [42].

\section{Conclusions}

The results of the present survey revealed that L. infantum infection in dogs is widespread in Sichuan Province, southwestern China, which has public health significance due to its contribution to the transmission of the infection to humans by sandflies. It is necessary to implement strategies, including treatment or eradication of infected dogs, to control canine leishmaniasis, which could help to reduce human VL in this area.

\section{Acknowledgements}

This work is supported by National High Technology and Development Program of China ("863" program) (2009AA10Z402), the Program for Changjiang Scholars and Innovative Research Team in University (IRT0848), and "Gold Idea" Foundation of Institute of Military Veterinary, Academy of Military Medical Sciences (YCX0901).

\section{Author details \\ ${ }^{1}$ Institute of Military Veterinary, Academy of Military Medical Sciences, Key Laboratory of Jilin Province for Zoonosis Prevention and Control, 666 Liuying Xilu, Changchun 130122, Jilin Province, People's Republic of China. ${ }^{2}$ College of Veterinary Medicine, Sichuan Agricultural University, 46 Xingkang Road, Ya'an 625014, Sichuan Province, People's Republic of China. ${ }^{3}$ Mianyang Center for Animal Disease Control and Prevention, 62 Fucheng Road, Mianyang 62100, Sichuan Province, People's Republic of China.}

\section{Authors' contributions}

LS and WP carried out real time PCR. WP, DX, NZ, WW and YW collected the samples. HJ and NZ performed data analysis. QL and NZ designed the study. $\mathrm{QL}$ drafted the manuscript. All authors read and approved the final manuscript.

\section{Competing interests}

The authors declare that they have no competing interests.

Received: 17 July 2011 Accepted: 12 September 2011 Published: 12 September 2011

\section{References}

1. Guerin PJ, Olliaro P, Sundar S, Boelaert M, Croft SL, Desjeux P, Wasunna MK, Bryceson AD: Visceral leishmaniasis: current status of control, diagnosis, and treatment, and a proposed research and development agenda. Lancet Infect Dis 2002, 2:494-501.

2. Albrecht $H$, Sobottka I, Emminger $C$, Jablonowski H, Just $G$, Stoehr A, Kubin T, Salzberger B, Lutz T, van Lunzen J: Visceral leishmaniasis emerging as an important opportunistic infection in HIV-infected persons living in areas nonendemic for Leishmania donovani. Arch Pathol Lab Med 1996, 120:189-198.
3. Alvar J, Aparicio P, Aseffa A, Den Boer M, Canavate C, Dedet JP, Gradoni L, Ter Horst R, Lopez-Velez R, Moreno J: The relationship between leishmaniasis and AIDS: the second 10 years. Clin Microbiol Rev 2008, 21:334-359.

4. Feng JJ, Shi SZ: Control strategies and epidemiology of visceral leishmaniasis in China. Journal of Medical Pest Control 2002, 18:458-461.

5. Osman Y, Gu DA, Zuo XP, Lan QX, Zhou XJ, Tong SX, Li X, Zhang Y, Jumahun $R$, Chen $W$, et al: An epidemiological survey of visceral leishmaniasis in Hamangou coal mine area of Korla City, Xinjiang. Chin J Parasitol Parasit Dis 2009, 27:237-240, (in Chinese).

6. Wang JY, Gao CH, Yang YT, Chen HT, Zhu XH, Lv S, Chen SB, Tong SX, Steinmann P, Ziegelbauer K, Zhou XN: An outbreak of the desert sub-type of zoonotic visceral leishmaniasis in Jiashi, Xinjiang Uygur Autonomous Region, People's Republic of China. Parasitol Int 2011, 59:331-337.

7. Gui AF, Zuo SL, Wu JH, Gui XE, Hu LQ, Yang LD, Zhang SQ: Evaluation of prevalent status of kala-azar in endemic area of Hubei Province. Chin J Parasitol Parasit Dis 2000, 18:170-172, (in Chinese).

8. Wang JY, Feng Y, Gao CH, Jin CF, Chen SB, Zhang CJ, He JP, Yang CM, Yang YT, Bao YF: Asymptomatic Leishmania infection in human population of Wenxian County, Gansu Province. Chin J Parasitol Parasit Dis 2007, 25:62-64, (in Chinese).

9. Wei F, Shang L, Jin H, Lian H, Liu W, Li Z, Gao H, Liu Q: Molecular detection and genetic diversity of Leishmania donovani in naturally infected Phlebotomus chinensi from southwestern China. Vector Borne Zoonotic Dis 2011, 11:849-852.

10. Wang JY, Ha Y, Gao CH, Wang Y, Yang YT, Chen HT: The prevalence of canine Leishmania infantum infection in western China detected by PCR and serological tests. Parasit Vectors 2011, 4:69.

11. de Paiva Diniz PP, Schwartz DS, de Morais HS, Breitschwerdt EB: Surveillance for zoonotic vector-borne infections using sick dogs from southeastern Brazil. Vector Borne Zoonotic Dis 2007, 7:689-697.

12. Christensen HA, Herrer A: Attractiveness of sentinel animals to vectors of leishmaniasis in Panama. Am J Trop Med Hyg 1973, 22:578-584.

13. Paradies P, Sasanelli M, de Caprariis D, Testini G, Traversa D, Lia RP, DantasTorres F, Otranto D: Clinical and laboratory monitoring of dogs naturally infected by Leishmania infantum. Vet J 2011, 186:370-373.

14. Molina R, Amela C, Nieto J, San-Andres M, Gonzalez F, Castillo JA, Lucientes J, Alvar J: Infectivity of dogs naturally infected with Leishmania infantum to colonized Phlebotomus perniciosus. Trans $R$ Soc Trop Med Hyg 1994, 88:491-493.

15. Maia C, Campino L: Methods for diagnosis of canine leishmaniasis and immune response to infection. Vet Parasitol 2008, 158:274-287.

16. Ashford DA, Bozza M, Freire M, Miranda JC, Sherlock I, Eulalio C, Lopes U, Fernandes O, Degrave W, Barker RH Jr, et al: Comparison of the polymerase chain reaction and serology for the detection of canine visceral leishmaniasis. Am J Trop Med Hyg 1995, 53:251-255.

17. Nasereddin A, Ereqat S, Azmi K, Baneth G, Jaffe CL, Abdeen Z: Serological survey with PCR validation for canine visceral leishmaniasis in northern Palestine. J Parasitol 2006, 92:178-183.

18. Reithinger R, Quinnell RJ, Alexander B, Davies CR: Rapid detection of Leishmania infantum infection in dogs: comparative study using an immunochromatographic dipstick test, enzyme-linked immunosorbent assay, and PCR. J Clin Microbiol 2002, 40:2352-2356.

19. da Silva ES, van der Meide WF, Schoone GJ, Gontijo CM, Schallig HD, Brazil RP: Diagnosis of canine leishmaniasis in the endemic area of Belo Horizonte, Minas Gerais, Brazil by parasite, antibody and DNA detection assays. Vet Res Commun 2006, 30:637-643.

20. Zhang FN, Chen YN, Xiao N: Analysis of cases and control measures of visceral leishmaniasis in Sichuan Province, China in 2006-2007. Chin J Zoonoses 2008, 24:1085-1086, (in Chinese)

21. Wei F, Shang L, Jin H, Lian H, Liu W, Li Z, Gao H, Liu Q: Molecular detection and genetic diversity of Leishmania donovani in naturally infected Phlebotomus chinensi from southwestern China. Vector Borne Zoonotic Dis 2011, 11:849-52.

22. Zhang $R$, Shang L, Jin H, Ma C, Wu Y, Liu Q, Xia Z, Wei F, Zhu XQ, Gao H: In vitro and in vivo antileishmanial efficacy of nitazoxanide against Leishmania donovani. Parasitol Res 2010, 107:475-479.

23. Nicolas L, Prina E, Lang T, Milon G: Real-time PCR for detection and quantitation of Leishmania in mouse tissues. J Clin Microbiol 2002, 40:1666-1669. 
24. Lu HG, Zhong L, Guan LR, Qu JQ, Hu XS, Chai JJ, Xu ZB, Wang CT, Chang KP: Separation of Chinese Leishmania isolates into five genotypes by kinetoplast and chromosomal DNA heterogeneity. Am J Trop Med Hyg 1994, 50:763-770.

25. Hu X, Bu L, Ma Y, Wang Y, Jing B, Yi T: Difference in DNA sequences in SSU rDNA variable regions among pathogens isolated from different epidemic foci of visceral leishmaniasis in China. Chin Med J (Engl) 2002, 115:1457-1459.

26. Li GR, JJ J, Jiang NF, Zhang Y, Liu L, Chen X: Evaluation of control measures of dogs-borne leishmaniasis in Sichuan Province, China. Parasit Infect Dis 2004, 2:74-76, (in Chinese).

27. Gao B, Chen GR, Yu T, Wei HY, Li JF: Analysis of visceral leishmaniasis cases in Sichuan Province, China during 1995-1999. Chin J Parasit Dis Control 2001, 14:28, (in Chinese).

28. Paradies P, Sasanelli M, de Caprariis D, Testini G, Traversa D, Lia RP, DantasTorres F, Otranto D: Clinical and laboratory monitoring of dogs naturally infected by Leishmania infantum. Vet J 186:370-373.

29. Paradies P, Capelli G, Cafarchia C, de Caprariis D, Sasanelli M, Otranto D: Incidences of canine leishmaniasis in an endemic area of southern Italy. J Vet Med B Infect Dis Vet Public Health 2006, 53:295-298.

30. Ozbel Y, Oskam L, Ozensoy S, Turgay N, Alkan MZ, Jaffe CL, Ozcel MA: A survey on canine leishmaniasis in western Turkey by parasite, DNA and antibody detection assays. Acta Trop 2000, 74:1-6.

31. Cruz I, Acosta L, Gutierrez MN, Nieto J, Canavate C, Deschutter J, BornayLlinares FJ: A canine leishmaniasis pilot survey in an emerging focus of visceral leishmaniasis: Posadas (Misiones, Argentina). BMC Infect Dis 2011, 10:342.

32. Solano-Gallego L, Llull J, Osso M, Hegarty B, Breitschwerdt E: A serological study of exposure to arthropod-borne pathogens in dogs from northeastern Spain. Vet Res 2006, 37:231-244.

33. Amusategui I, Sainz A, Aguirre E, Tesouro MA: Seroprevalence of Leishmania infantum in northwestern Spain, an area traditionally considered free of leishmaniasis. Ann N Y Acad Sci 2004, 1026:154-157.

34. Tabar MD, Roura X, Francino O, Altet L, Ruiz de Gopegui R: Detection of Leishmania infantum by real-time PCR in a canine blood bank. J Small Anim Pract 2008, 49:325-328.

35. Chargui N, Haouas N, Gorcii M, Lahmar S, Guesmi M, Ben Abdelhafidh A, Mezhoud $\mathrm{H}$, Babba $\mathrm{H}$ : Use of PCR, IFAT and in vitro culture in the detection of Leishmania infantum infection in dogs and evaluation of the prevalence of canine leishmaniasis in a low endemic area in Tunisia. Parasite 2009, 16:65-69.

36. Biglino A, Bolla C, Concialdi E, Trisciuoglio A, Romano A, Ferroglio E: Asymptomatic Leishmania infantum infection in an area of northwestern Italy (Piedmont region) where such infections are traditionally nonendemic. J Clin Microbiol 2011, 48:131-136.

37. Moshfe A, Mohebali M, Edrissian G, Zarei Z, Akhoundi B, Kazemi B, Jamshidi S, Mahmoodi M: Canine visceral leishmaniasis: asymptomatic infected dogs as a source of L. infantum infection. Acta Trop 2009, 112:101-105

38. Biglino A, Bolla C, Concialdi E, Trisciuoglio A, Romano A, Ferroglio E: Asymptomatic Leishmania infantum infection in an area of northwestern Italy (Piedmont region) where such infections are traditionally nonendemic. J Clin Microbiol 48:131-136.

39. Iniesta L, Fernandez-Barredo S, Bulle B, Gomez MT, Piarroux R, Gallego M, Alunda JM, Portus M: Diagnostic techniques to detect cryptic leishmaniasis in dogs. Clin Diagn Lab Immunol 2002, 9:1137-1141.

40. Otranto D, Paradies P, de Caprariis D, Stanneck D, Testini G, Grimm F, Deplazes $P$, Capelli G: Toward diagnosing Leishmania infantum infection in asymptomatic dogs in an area where leishmaniasis is endemic. Clin Vaccine Immunol 2009, 16:337-343.

41. Lachaud L, Chabbert E, Dubessay P, Dereure J, Lamothe J, Dedet JP, Bastien P: Value of two PCR methods for the diagnosis of canine visceral leishmaniasis and the detection of asymptomatic carriers. Parasitology 2002, 125:197-207.

42. Solano-Gallego L, Koutinas A, Miro G, Cardoso L, Pennisi MG, Ferrer L, Bourdeau P, Oliva G, Baneth G: Directions for the diagnosis, clinical staging, treatment and prevention of canine leishmaniosis. Vet Parasitol 2009, 165:1-18. doi:10.1186/1756-3305-4-173

Cite this article as: Shang et al:: The prevalence of canine Leishmania infantum infection in Sichuan Province, southwestern China detected by real time PCR. Parasites \& Vectors 2011 4:173.

\section{Submit your next manuscript to BioMed Central and take full advantage of:}

- Convenient online submission

- Thorough peer review

- No space constraints or color figure charges

- Immediate publication on acceptance

- Inclusion in PubMed, CAS, Scopus and Google Scholar

- Research which is freely available for redistribution

Submit your manuscript at www.biomedcentral.com/submit
Biomed Central 